\title{
PENGARUH PENAMBAHAN LABU KUNING (CUCURBITA MOSCHATA) DAN IKAN GABUS (OPHIOCEPHALUS STRIATUS) TERHADAP MUTU ORAGNOLEPTIK, KADAR PROTEIN DAN VITAMIN A BISKUIT
}

\author{
Putri Aulia Arza - Sepni Asmira
}

Stikes Perintis Padang

tilla.arza@gmail.com

\begin{abstract}
Nutrition potential and availability of pumpkin and cork in Indonesia are abundant, so diversification of pumpkin and cork fish in biscuit making is expected to be a more nutritious food alternative. This study was an experimental study using a complete randomized design consisting of three treatments, one control and two replications. This study was conducted in January - June 2016. Observations were made on organoleptic characteristics and protein content of biscuits. The subjective observation result using organoleptic test showed that the level of panelist's preference for color and texture was on treatment A (control) without the addition of pumpkin and cork fish. As for the aroma and taste with the best result is on the treatment of $C$ with the ratio of pumpkin and cork fish $(20 \mathrm{~g}: 20 \mathrm{~g})$. The highest protein content was found in $D$ treatment with the addition of pumpkin and cork fish (30 g: $30 \mathrm{~g})$. Based on the results of research conducted, the addition of yellow squash and cork fish affect the color of biscuits and protein content of biscuits.
\end{abstract}

Keywords: Biscuits, pumpkin, cork fish, organoleptic, and protein.

\section{PENDAHULUAN}

Kurang Energi Protein adalah salah satu masalah gizi utama disamping masalah gizi lainnya. Kurang Energi Protein (KEP) disebabkan oleh 
kekurangan makan sumber energi secara umum dan kekurangan sumber protein.Untuk mengatasi masalah tersebut perlu dilakukan perbaikan kebiasaan makan masyarakat yaitu dengan diversifikasi dan substitusi pangan dengan pangan-pangan yang mudah didapat, murah dan kaya zat giz (Muchtadi 2010).

Labu kuning (Cucurbita moschata Duschenes) merupakan salah satu bahan pangan lokal yang memiliki nilai gizi yang baik bagi tubuh manusia. Tanaman labu kuning dapat tumbuh di dataran rendah maupun dataran tinggi sehingga cocok juga tumbuh di Sumatera Barat, khususnya kabupaten Solok, Agam dan tanah Datar memiliki potensi labu kuning yang cukup besar. Kabupaten Solok menurut data Sumbar dalam Angka tahun 2011, areal tanam mencapai 45 hektare dengan total produksi 1.025 ton (Nurhidayati 2011).

Kandungan gizi dari labu kuning yang cukup tinggi yaitu betakaroten sebesar $1569 \mu \mathrm{g} / 100 \mathrm{~g}$ bahan, dan juga mengandung gizi lain berupa karbohidrat, protein, lemak, serat, beberapa mineral seperti kalsium, fosfor, besi, serta vitamin yaitu Vitamin A, B dan C dan serat. Warna kuning daging buahnya pertanda kandungan karotenoidnya sangat tinggi (Nurhidayati 2011).

Protein juga sangat dibutuhkan oleh tubuh kita, karena protein berfungsi sebagai salah satu sumber energi yang dibutuhkan tubuh.Usaha yang dapat dilakukan untuk memenuhi kebutuhan protein adalah dengan cara pemanfaatan bahan alam yang memiliki kandungan protein yang tinggi. Ikan gabus (Ophiocephalus striatus) merupakan salah satu sumber protein hewani yang lengkap dan bermutu tinggi karena mempunyai kandungan asam-asam amino esensial yang lengkap dan susunannya mendekati asam amino yang diperlukan tubuh, serta daya cernanya tinggi sehingga jumlah yang dapat diserap juga tinggi (Muchtadi 2010). Ikan gabus juga merupakan bahan sumber albumin yang potensial, dapat digunakan sebagai bahan sumber biofarma dan bahan subtitusi albumin manusia (Moedjiharto 2007).

Penelitian Syandri et al. (2009) mengungkapkan 19 spesies ikan perairan air tawar hidup di habitat Danau Singkarak, Kabupaten Solok dan Tanah Datar, Sumatera Barat (Sumbar), dengan ketersediaan bahan makanannya yang terbatas, salah satunya adalah ikan gabus. Ikan gabus banyak ditemukan di 
perairan umum dan belum di budidayakan secara luas, ikan gabus hidup di muara sungai, danau, rawa, dan dapat pula hidup di air kotor dengan kadar oksigen rendah serta tahan terhadap kekeringan (Bijaksana 2012).

Mengingat potensi gizi dan ketersediaan labu kuning dan ikan gabus di Indonesia yang berlimpah, maka upaya diversifikasi labu kuning dan ikan bagus menjadi pangan fungsional perlu dilakukan antara lain dengan mengolah labu kuning dan ikan gabus menjadi biskuit. Biskuit adalah salah satu produk olahan kue kering yang merupakan makanan ringan yang disenangi karena enak, manis, dan renyah serta memiliki umur simpan cukup lama (Kusnandar et al. 2010). Dari uraian tersebut, peneliti ingin melakukan penelitian mengenai optimalisasi biskuit menggunakan bahan baku labu kuning dan ikan gabus.

\section{METODE}

Jenis penelitian ini adalah eksperimen dengan menggunakan RAL (Rancangan Acak Lengkap) dengan 3 (tiga) perlakuan, 1 kontrol dan 2 x ulangan. Penelitian ini telah dilakukan pada bulan Januari - Juni 2016 di Laboratorium makanan STIKes Perintis Padang untuk uji organoleptik dan untuk pengujian kadar protein dilakukan di Laboratorium Balai Riset Dan Standarisasi Industri Padang.

Data yang dikumpulkan meliputi data yang diuji secara subjektif dan secara objektif. Pengumpulan data subjektif meliputi uji organoleptik (warna, uji bau/aroma, tekstrur dan rasa) dan pengumpulan data secara objektif meliputi analisis kadar protein biskuit yang dilakukan sebelum dan setelah penambahan labu kuning dan ikan gabus dengan perbandingan yang berbeda. Uji organoleptik adalah uji yang dilakukan untuk mengetahui warna, rasa, aroma dan tekstur dari penambahan labu kuning dan ikan gabus pada biskuit. Untuk mendapatkan hasil dari uji organoleptik diperlukan panelis, panel yang digunakan pada penelitian ini adalah panelis agak terlatih yang mana panelis terdiri dari 25 orang yaitu Mahasiswa S1 Gizi STIKes Perintis Semester 6.

Data yang diperoleh dari hasil pengujian organoleptik dianalisa berdasarkan tingkat kesukaan untuk aroma, tekstur, warna dan rasa. Hasil uji 
organoleptik disajikan dalam bentuk tabel untuk dihitung nilai rata - rata kemudian dianalisa menggunakan analisis sidik ragam ( $A N O V A$ ) pada taraf nyata $5 \%$. Jika terdapat perbedaan antar perlakuan, dilanjutkan dengan uji Duncan New Multiple Range Test (DNMRT) pada taraf nyata 5\%.

\section{HASIL DAN PEMBAHASAN}

\section{Uji Organoleptik}

\section{Warna}

Tingkat kesukaan panelis terhadap warna berkisar antara 3,18 sampai 3,64. Berdasarkan uji organoleptik perbandingan penambahan labu kuning dan ikan gabus berpengaruh nyata terhadap warna biskuit. Dari keempat perlakuan yang paling disukai panelis adalah perlakuan A yang merupakan pelakuan kontrol tanpa penambahan labu kuning dan ikan gabus, dimana warna biskuitnya putih kecoklatan. Adapun semakin tinggi penambahan labu kuning dan ikan gabus, biskuit semakin kekuningan. Warna merupakan salah satu faktor yang menentukan mutu dan secara visual warna tampil lebih dahulu dan kadang-kadang sangat menentukan, sehingga warna dijadikan atribut organoleptik yang penting dalam suatu bahan pangan (Winarno 2004). Warna dapat menentukan mutu bahan pangan, dapat digunakan sebagai indikator kesegaran bahan makanan, baik tidaknya cara pencampuran atau pengolahan. Suatu bahan pangan yang disajikan akan terlebih dahulu dinilai dari segi warna.

Warna terbaik biskuit adalah pada perlakuan kontrol yaitu tanpa penambahan labu kuning dan ikan gabus. Hal ini disebabkan karena perlakuan dengan penambahan labu kuning dan ikan gabus menghasilkan warna yang sangat kuning serta kandungan karoten pada labu kuning sangat tinggi, seperti lutein, zeaxanthin, dan karoten, yang memberi warna kuning pada labu kuning yang membantu melindungi tubuh dengan menetralkan molekul oksigen jahat yang disebut juga radikal bebas. (Winarno 2004).

Menurut Rohimah (2012), pada pembuatan biskuit dengan penambahan tepung labu kuning dan ikan lele tingkat kesukaan panelis terhadap warna menunjukkan bahwa biskuit dengan penambahan tepung labu 
kuning dan ikan lele 20\% disukai oleh anak SD dan mahasiswa FKM USU sedangkan pada ibu hamil menyukai biskuit tepung labu kuning dan ikan lele $30 \%$. Warna tepung labu kuning dan ikan lele memang berpengaruh terhadap warna produk biskuit yang dihasilkan, semakin banyak konsentrasi penggunaan tepung labu kuning dan ikan lele, warna biskuit akan semakin kuning kecoklatan.

\section{Tekstur}

Tingkat kesukaan panelis terhadap tekstur biskuit berkisar anatara 2,98 sampai 3,54. Dari keempat perlakuan tekstur yang paling disukai panelis adalah perlakuan A (kontrol) dimana perlakuan ini tanpa penambahan labu kuning dan ikan gabus, tekstur biskuitnya lebih halus. Adapun biskuit dengan penambahan labu kuning dan ikan gabus teksturnya lebih kasar dan tidak terlalu renyah. Indikator yang kedua yaitu tekstur. Tekstur terbaik biskuit labu kuning dan ikan gabus adalah perlakuan A, yaitu tanpa penambahan labu kuing dan ikan gabus. Dimana tekstur biskuitnya lebih halus, sedangkan biskuit dengan penambahan labu kuning dan ikan gabus teksturnya lebih kasar dan tidak terlalu renyah / lunak.

Biskuit dengan penambahan labu kuning dan ikan gabus yang semakin tinggi memiliki tekstur yang kurang sempurna. Hal tersebut disebabkan oleh minimnya kadar air. Kadar air yang rendah disebabkan oleh sifat higroskopis pada konsentrat protein ikan (Dewita dan Syahrul 2010). Pradipta dan Widya (2015) menyatakan bahwa kadar air yang rendah mmbutuhkan waktu yang lebih lama untuk menghasilkan tekstur biskuit yang sempurna.

Hal ini juga didukung oleh pendapat Fatma et al. (2009) bahwa biskuit merupakan sejenis makanan kering, sehingga kadar air sangat menetukan mutu dari biskuit oleh karena itu kadar air perlu dibatasi 5-10\%, karena dapat mengakibatkan tekstur biskuit kurang renyah jika melewati batas tersebut. Berdasarkan penelitian yang dilakukan oleh Rohimah (2012), pembuatan biskuit dengan penambahan tepung labu kuning dan ikan lele hasil uji daya terima terhadap tekstur menunjukkan bahwa biskuit dengan penambahan 
tepung labu kuning dan ikan lele 20\% sangat disukai. Sedangkan pada ibu hamil menyukai tekstur dengan penambahan 40\% yang teksturnya agak keras karena berbeda dari biskuit pada umumnya.

\section{Aroma}

Tingkat kesukaan panelis terhadap aroma biskuit berkisar anatara 3,04 sampai 3,36. Dari keempat perlakuan aroma yang paling disukai panelis adalah perlakuan B dimana penambahan labu kuning dan ikan gabus $10 \mathrm{~g}$, yaitu 3,36 dengan aroma biskuit yang netral. Aroma makanan banyak menentukan kelezatan makanan tersebut, oleh karena itu aroma merupakan salah satu faktor dalam penentuan mutu. Winarno (2004), aroma yang khas dan menarik dapat membuat makanan lebih disukai oleh konsumen sehingga perlu diperhatikan dalam pengolahan suatu bahan makanan.

Dari hasil penelitian aroma terbaik dari biskuit adalah pada perlakuan B dengan penambahan labu kuning dan ikan gabus (10 g : $10 \mathrm{~g})$. Hal ini dipengaruhi oleh bahan dasar penambahan labu kuning yang mempengaruhi aroma biskuit yang dihasilkan. Hal ini sesuai dengan pendapat Hendrasty (2006), labu kuning mempunyai sifat spesifik dengan aroma khas. Menurut Rohimah (2012), pada pembuatan biskuit dengan penambahan tepung labu kuning dan ikan lele tingkat kesukaan panelis terhadap aroma hasil uji daya terima anak SD, mahasiswa FKM USU dan ibu hamil yang telah dilakukan dengan menggunakan pengujian organoleptik terhadap aroma menunjukkan penambahan tepung labu kuning dan ikan lele 20\% yang disukai oleh anak SD dan mahasiwa FKM USU, sedangkan pada ibu hamil kurang menyukai biskuit tepung labu kuning dan ikan lele karena masih beraroma amis dari ikan lele.

\section{Rasa}

Tingkat kesukaan panelis terhadap rasa biskuit berkisar anatara 2,88 sampai 3,42. Rasa yang paling disukai panelis dari keempat perlakuan adalah perlakuan B, biksuit dengan penambahan labu kuning dan ikan gabus $10 \mathrm{~g}$ yaitu 3,42. Dimana rasa labu kuning dan ikan gabus nya tidak terlalu khas. Cita 
rasa makanan merupakan salah satu faktor penentu bahan makanan. Makanan yang memiliki rasa yang enak dan menarik akan disukai oleh konsumen. (Winarno 2004). Rasa biskuit yang paling disukai panelis adalah pada perlakuan B yaitu perbandingan penambahan labu kuning dan ikan gabus nya (10:10).

Penambahan labu kuning yang mempengaruhi rasa biskuit yang dihasilkan. Hal ini sesuai dengan pernyataan dari Winarno (2004), bahwa tekstur dan konsistensi bahan akan mempengaruhi citarasa yang ditimbulkan oleh bahan tersebut. Perubahan tekstur atau viskositas bahan dapat ditimbulkan oleh bahan tersebut dapat merubah bau dan rasa. Berdasarkan penelitian yang dilakukan oleh Rohimah (2012), pembuatan biskuit dengan penambahan tepung labu kuning dan ikan lele hasil uji daya terima terhadap rasa. Uji daya terima terhadap rasa menunjukkan bahwa rasa biskuit dengan penambahan tepung labu kuning dan ikan lele 20\% disukai oleh anak SD dan mahasiwa FKM USU karena rasanya manis dan gurih. Sedangkan ibu hamil kurang menyukai rasa biskuit tepung labu kuning dan ikan lele karena memiliki aroma rasa dari ikan lele yang khas.

\section{Analisis Kadar Protein}

Tabel 1 menunjukkan bahwa kadar protein tertinggi pada perlakuan D (penambahan labu kuning dan ikan gabus 30 gr : 30 gr). Lebih banyak penambahan labu kuning dan ikan gabus pada biskuit maka dapat meningkatkan kadar protein pada biskuit.

Tabel 1 Kadar Protein Biskuit

\begin{tabular}{lc}
\hline \multicolumn{1}{c}{ Komposisi Biskuit } & \% Kadar Protein \\
\hline Tanpa Penambahan Labu Kuning dan Ikan Gabus (Kontrol) & 4,18 \\
Dengan Penambahan Labu Kuning dan Ikan Gabus (10 g: $10 \mathrm{~g})$ & 6,57 \\
Penambahan Labu Kuning dan Ikan Gabus (20 g : $20 \mathrm{~g})$ & 7,55 \\
Penambahan Labu Kuning dan Ikan Gabus (30 g: $30 \mathrm{~g})$ & 7,6 \\
\hline
\end{tabular}

Hasil penelitian menunjukkan bahwa kandungan protein tertinggi terdapat pada formula 'Penambahan Labu Kuning dan Ikan Gabus (30 g: 30 
g)'. Semakin tinggi penambahan labu kuning dan ikan gabus akan meningkatkan kadar protein. Hal tersebut disebabkan oleh tingginya kadar protein dalam ikan gabus dan labu kuning. (Trilaksani et al 2014).

\section{KESIMPULAN}

Terdapat pengaruh penambahan labu kuning dan ikan gabus terhadap warna, tekstur, aroma dan rasa biskuit. Formulasi terbaik pada biskuit dengan penambahan labu kuning dan ikan gabus untuk warna dan tekstur adalah pada perlakuan A yaitu tanpa penambahan labu kuning dan ikan gabus. Sedangkan formulasi terbaik untuk aroma dan rasa adalah pada perlakuan B yaitu penambahan labu kuning dan ikan gabus (10 gr : 10 gr). Kadar protein tertinggi adalah biscuit dengan penambahan ikan gabus dan labu kuning sebesar 30:30 gr.

\section{DAFTAR PUSTAKA}

Kementrian Kesehatan RI. 2014. Laporan Nasional Riset Kesehatan Dasar (Riskesdas) tahun 2013. Jakarta: Kemenkes RI

Badan Pusat Statistik. 2011. Sumatera Barat dalam Angka. BPS. Sumatera Barat. Bijaksana U. 2012. Domestikasi Ikan Gabus, Channa striata Blkr, Upaya Optimalisasi Perairan Rawa di Provinsi Kalimantan Selatan. [Skripsi] Banjar Baru: Program Studi Perairan, Fakultas Perikanan dan Ilmu Kelautan, Universitas Lambung Mangkurat.

Dewita, Syahrul. 2010. Kajian mutu konsentrat protein ikan patin (Pangasius Sp) yang diolab dengan metode berbeda selama penyimpanan subu kamar. Jurnal Natur Indonesia in press.

Direktorat Gizi Departemen Kesehatan R.I., 1996. Daftar Komposisi Bahan Makanan. Jakarta : Bhratara Karya Aksara.

Hendrasty, Henny K. 2003. Tepung Labu Kuning, Pembuatan dan Pemanfaatannya. Yogyakarta: Kanisius.

Kusnandar F. 2010. Kimia Pangan Komponen Makro. Jakarta: Penerbit Dian Rakyat. 
Moedjiharto TJ. 2007. Ikan sebagai bahan substitusi human serum albumin (HSA) dalam penyumbang biofarma Indonesia. http://old-prasetya.ub.id. [28 April 2011].

Muchtadi D. 2010. Teknik Evaluasi Nilai Giz̨i Protein. Bandung: Penerbit Alfabeta.

Nurhidayati. 2011. Kontribusi MP-ASI Biskuit Bayi dengan Substitusi Tepung (Cucurbita moschata) dan Tepung Ikan patin ( Pangasius spp) terbadap Kecukupan Protein dan Vitamin A [Artikel Penelitian]. Semarang: Program Studi Ilmu Gizi Fakultas Kedokteran. Universitas Diponegoro.

Pradipta IBYV, Widya DWP. 2015. Pengarub Proporsi Tepung Terigu dan Tepung Kacang Hijau Serta Subtitusi Dengan Tepung Bekatul dalam Biskuit. Jurnal Pangan dan Agroindustri. 3 (3): 793-802.

SNI. 1992. Biskuit SNI 01-2973-1992. Jakarta: Badan Standarisasi Nasional.

SNI 2973-2011. Biskuit. Dewan Standarisasi Nasional

Syandri et al. 2012. Karakterisasi Morfologi Ikan Bujuk (Channa lucius) pada Perairan Danau Singkarak Sumatera Barat, Rawa Banjiran Tanjung Jabung Timur Jambi dan Rawa Banjiran Kampar Riau. Universitas Bung Hatta, Padang Jurnal Natur Indonesia 15 (1): 1-8

Winarno 2004. Kimia Pangan Dan Gizi. Jakarta : Penerbit PT Gramedia.

World Health Organization (WHO). (2012). About Malnutrition. http://www.who.int/action_online/basics/en/index3.html 